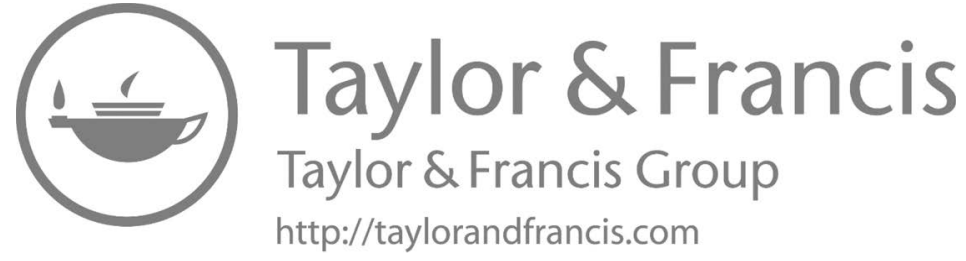




\title{
15
}

\section{PANDEMIC GOVERNANCE IN INDIA}

\section{The ongoing shift to 'national federalism'}

\author{
Ajay Kumar Singh
}

\subsection{Introduction}

Covid-19 broke out in India in January 2020, soon placing a federation already embattled by authoritarian centralism under strain, yet without successfully containing the spread of the pandemic in what, after China, is the second-most populous country in the world. The pandemic further pushed the polity towards national federalism, emphasising national executive governance of public policies and state subjects.

With a population density of 382 per $\mathrm{km}^{2}$, India's population, according to the 2011 census, stood at 1.21 billion in 2011 (Union Ministry of Information and Broadcasting 2020: 7), while estimates by the United Nations in 2019 put the figure as high as 1.37 billion (United Nations, Department of Economic and Social Affairs, Population Division 2019: 12). Roughly 29.5 per cent of people are in the age group 0-14 years, 62.5 per cent in the age group 14-59 years, and 8 per cent 60 years and older (Office of the Registrar General and Census Commissioner of India 2011). About 31.2 per cent of the population reside in urban areas that range from towns to cities and metropolises. Hindus comprise approximately 79.8 per cent of the population, followed by Muslims (14.2 per cent), Christians (2.3 per cent), Sikhs (1.7 per cent), Buddhists ( 0.7 per cent), and Jain (0.3 per cent).

Politically and administratively, India is a federation consisting of 28 states and nine union (or federal) territories, 734 districts, 4,470 urban bodies, and 255,544 village panchayats (grass-roots councils). Over the past decade, especially since 2014, parliamentary democracy has been overshadowed by what many regard as an authoritarian regime in the form of the Bharatiya Janata Party (BJP), a right-wing Hindu formation which rules at the centre and in most of the states 
demonstrates little respect for constitutional principles. Secularism and multiculturalism have been under attack in the face of the BJP's efforts to establish a Hindu-ised socio-political order, with anti-minority sentiment and exclusionary politics becoming the norm (Diamond 2020: 1-7; Gandhi 2020: 1-4; Mukherji 2020: 91-105; Patnaik 2019: 6-9; Picketty 2020: 944-948).

Notably, in August 2019, the special autonomy status of Jammu and Kashmir regions was revoked (Basu 2020: 287-294), while in December, amendments under the Citizenship (Amendment) Act 47 of 2019 granted citizenship to members of non-Muslim religious communities from Afghanistan, Bangladesh or Pakistan who had entered India by 31 December 2014 (Tharoor 2020: 258-277; Union Ministry of Law and Justice 2019). This led to violent protests, with fears being voiced that the Act is discriminatory to Muslims and intended to make indigenous peoples minorities in their homelands.

Other aspects of India's democracy are also in danger. Freedom of expression is suppressed by state organs such as police, investigative agencies, surveillance systems, and tax authorities (Yadav 2020: 351). Parliamentary processes are subverted in the making and amendment of laws; parliamentary accountability is at its lowest ebb; and the autonomy of independent institutions, including the judiciary, Election Commission, Central Information Commission, and other regulatory bodies, is under constant threat (Ramakrishnan 2020). The pandemic has further incentivised illiberal repressive measures by Prime Minister Narendra Modi's government (Diamond 2020: 1-7; Mukherji 2020: 91).

Economically, at the beginning of 2020 India found itself in the midst of a growth crisis, one that worsened as the pandemic unfolded. Gross domestic product (GDP) has been in decline since 2016, when it recorded growth of 8.2 per cent. By 2019, GDP decreased by 3 per cent (World Bank 2020), after which it saw negative growth of 23.9 per cent in the first quarter (April-June) and 8.6 per cent in the second quarter (July-September) of the 2020-2021 fiscal year (Reserve Bank of India 2020). Unemployment, always a cause of concern, was aggravated by the pandemic, with salaried jobs decreasing from 86 million in 2019-2020 to 65 million in August 2020 (Vyas 2020).

On the medical front, India has a three-tier system consisting of primary health care (provided at sub-district level), secondary health care (provided at district level), and specialised services at the tertiary level. Public health expenditure has, however, never exceeded 1.6 per cent of GDP (PRS Legislative Research 2020a: 1), resulting in a significant misalignment in India between population size and health infrastructure; likewise, the doctor-population ratio is low at 1:1,343. The country has about a thousand district hospitals, 5,335 community health centres, 24,855 primary health centres, and 157,411 sub-centres in outlying areas. More tellingly, Jaffrelot and Shah (2020), referring to a study by the Centre for Disease Dynamics, Economics and Policy (India) and Princeton University, noted that 'public hospitals have only 713,986 beds, including 35,699 in intensive care units and 17,850 ventilators'. 
It was in this context that India reported its first case of Covid-19 on 30 January 2020, with the infection coming to light in the state of Kerala; the first Covid-19 death occurred on 12 March. The authorities continued with their wait-andsee policy until $14 \mathrm{March}$, at which point the pandemic was declared a national health emergency. Prior to this, the official response was virtually non-existent. Health screening at airports and international borders was not up to the standards set in World Health Organization (WHO) advisories, and almost no cases were reported in the intervening month of February.

When the first national lockdown was announced on 24 March 2020, India had only 519 recorded cases. Between then and 31 October, it conducted 108.8 million tests, with the total number of cases amounting to 8.1 million; during this period, 121,000 people died of Covid-19. In terms of territorial distribution, nearly all states and union territories were affected. However, about 75 per cent of cases were reported in ten states, namely, Andhra Pradesh, Chhattisgarh, Delhi, Karnataka, Kerala, Maharashtra, Tamil Nadu, Rajasthan, Uttar Pradesh, and West Bengal (Union Ministry of Health and Family Welfare 2020a). About 130 districts were hotspots, while the worst affected cities included Mumbai, Chennai, Delhi, and Ahmadabad. In a cumulative analysis, 97.72 per cent of the cases were reported during the period of phased reopening from 1 June to 31 October, which supports the thesis that India imposed a national lockdown too early and hastily.

This chapter argues that, under the helm of Prime Minister Narendra Modi, India's response to the pandemic resulted in the suspension of federalism in favour of highly centralised, unitary executive governance, and, concomitantly, severe curtailment of state autonomy. Elsewhere, I have argued that Indian federalism since 2014 (the year the BJP rose to power) is best described as undergoing a phase of national federalism marked by a shift of sovereignty from states to the centre and from the centre to the Office of the Prime Minister (Singh 2019). Pandemic governance is no exception to this trend. It is also argued that centralisation has not yielded the desired result of containing and managing Covid19, which instead has placed further strain on centre-state relations, particularly when it comes to fiscal issues.

\subsection{The federal constitutional and legislative framework}

India's union model of federalism is a curious blend of the characteristics of dual, cooperative-collaborative, and organic-interdependent federalism (Singh 2009). Under the Constitution of India of 1950, the distribution of powers between the different levels of government tilts the balance in favour of a strong centre, with centralisation rationalised as a measure to secure national unity and interests, promote general public welfare, and advance national economic integration (Jain 2019: 739).

Schedule 7 of the Constitution grants the centre residual powers and exclusive authority over 97 subjects including the deployment of the central armed forces; 
major industrial operations; national highways and transport (including interstate movements of goods, services, and people); regulation of higher education; inter-state migration and quarantine; and offences against union laws.

In comparison, important competences of states pertaining to Covid-19 are public order and safety; policing; public health and sanitation; hospitals and dispensaries; local and intra-state transport and communications; agriculture and allied activities; local industry and manufacturing; market operations; theatres, amusement parks, and the like; civil works and construction; and school and university education. In many of these subjects, states have only qualified and conditional competence. For example, in public health matters, the central government regulates clinical trials, treatment protocols, drug use, and medical standards, in addition to disease-specific measures (Singh 2015: 139-142).

States and the centre have shared competencies in matters such as civil and criminal law and procedure, social and economic planning, labour, education, social security, and employment. Nevertheless, central laws and regulations override state laws.

The Constitution provides for only two kinds of national emergency - the first due to war, external aggression or armed rebellion, and the second a financial emergency in which India's fiscal stability is under threat. In the event of a breakdown of governance in a state, presidential rule from the centre is imposed on the state. The declaration of an emergency is subject to parliamentary approval within a specified period (Basu 2019: 15061-233). In the absence of constitutional provisions specifically dealing with a pandemic emergency, the central government invoked three legislative enactments to declare a national pandemic emergency on 15 March 2020: the Epidemic Diseases Act (EDA) of 1897, the Disaster Management Act (DMA) of 2005 and Criminal Procedure Code (CPC) 1973 (Parliament of India, Rajya Sabha 2020a). The EDA was used to declare Covid-19 a national pandemic and the DMA to declare it as a 'notified disaster' and a 'national health emergency'. The CPC 1973 enabled police and other authorities engaged in pandemic management to take preventive and punitive action on any breach of the government's order on Covid-19 and to impose punishment for offences.

The EDA has four significant features: it allows the centre to declare a dangerous epidemic a national pandemic; it empowers state authorities to initiate corrective, preventative and regulatory control measures which are otherwise not feasible under the ordinary laws; it allows the government to inspect passenger traffic on air, land, or water and detain any person; and it protects health-care providers from any act of violence committed by any individual or group (PRS Legislative Research 2020b). The EDA was invoked previously during outbreaks of malaria, cholera, dengue, and swine flu (Nomani and Parveen 2020: 156).

The DMA 2005 was invoked, for the first time, to declare Covid-19 a national health emergency. The central government assumed all powers from the local to the national level related to pandemic care, control, and management. The DMA also empowers the central government to issue directives and orders on pandemic 
management and related matters. The orders made by the centre are binding (although barely accountable to Parliament); conversely, states and local authorities cannot take any measures contrary to central directives. For instance, during the phased reopening after India's lockdown, states wished to regulate inter- and intra-state movement of people but could not contradict an order of the central authority forbidding this.

\subsection{Preparedness for a national disaster: The institutional framework}

After enacting the DMA in 2005, India established a three-layered hierarchy for managing disasters, with the National Disaster Management Authority (NDMA; hereafter 'National Authority') at the central or national level, the State Disaster Management Authority (SDMA) at the state level, and the District Disaster Management Authority (DDMA) at the local level.

The National Authority is led by the Prime Minister: in the event of emergency, he or she can 'exercise all or any of the powers of the National Authority' (DMA 2005, section 3), which are ratified ex post facto by the NDMA. The latter comprises not more than nine members, each of whom is nominated by the Prime Minister; currently, it has five expert members. The NDMA is vested with the authority of planning and policy formulation. It approves the disaster management plans prepared by ministries, as well as coordinating and enforcing the policies and guidelines it prepares or approves; accordingly, it also has the authority to direct central ministries, departments, and state and district authorities in compliance with its orders and guidelines. It ensures funding and other measures of support necessary for disaster management. The National Authority can sanction concessional loans to persons and establishments affected by disaster of a severe magnitude, in addition to providing for basic necessities such as food, shelter, and health care. In other words, ensuring social and economic welfare is a principal responsibility of the National Authority.

The National Authority is assisted by the National Executive Committee (NEC). Headed by the union home secretary, it is a committee of secretaries in charge of ministries or departments involved in disaster-management work. As a 'coordinating and monitoring body for disaster management', the NEC is responsible for the preparation of a national plan to be approved by the National Authority, which lays down guidelines and their administration by departments of the central government as well as state authorities and ministries. It monitors and evaluates progress in disaster mitigation and management.

The SDMA in turn is headed by the chief minister of the state concerned. In case of a localised state disaster, the state authority has powers and functions similar to those of the National Authority. However, in the event of a declaration of a national disaster, its authority has no autonomous domain. Like the National Authority, the state authority is assisted by the State Executive 
Committee (SEC), which is chaired by the state chief secretary - the latter is the executive officer responsible for implementing disaster mitigation plans and guidelines issued by the state authority.

The district authority is in charge of district-level planning and led by the district magistrate, collector or deputy commissioner, who appoints executive magistrates as 'incident commanders' responsible for the implementation of disaster mitigation measures in their respective local jurisdictions. All other line department officials work under the instruction of the chair of the DDMA, which means in practice that panchayats and municipal authorities serve under his or her authority.

In declaring Covid-19 an epidemic, the National Authority (read: the Prime Minister) on 24 March 2020 invoked its power under the DMA 2005 to 'direct ministries/departments of government of India, state governments and state authorities' to take nationally consistent and uniform measures for the prevention of the spread of disease (section 6(2)(i)). It further authorised the NEC to issue necessary guidelines.

In this context, three sections of the DMA 2005 must be highlighted. Section 35 allows the central government unilaterally to control, command, and coordinate disaster measures across India, while section 62 endows it with extraordinary authority to issue directives to statutory authorities, officers, and employees at any level of government. In other words, the pandemic is to be governed through a unified system of command and compliance. Furthermore, section 65 grants the leviathan of the state the 'power of requisition of resources, provisions, vehicles, etc.' from any public authority or person.

In summary, in the event of disasters of a national scale, the DMA 2005 provides for a pyramidal structure of governance with the Prime Minister at the top and incident commanders at the bottom. Authority begins and ends with the Prime Minister. It is from here that the overall national power structure, its political composition, ideologies, and leadership have a determining impact on disaster management.

\subsection{Rolling out measures to contain the pandemic}

When the pandemic struck, the BJP - either on its own or as part of the National Democratic Alliance (NDA) - was firmly in control at the centre and in 21 states, which approximates to about 70 per cent of India's population. The Indian National Congress (INC) party is in power in but five states, the Communist Party of India in one, and other regional or local parties preside over three states (Maps of India 2020). Of the 545 seats in the Lok Sabha ('House of the People'), the lower chamber of India's bicameral parliament, the BJP has 302 and the INC only 51; of the 250 seats in the upper house of parliament, the BJP has 92 and the INC, 37. The picture which emerges is that India has a nationally weak opposition, and hence one that cannot ensure the accountability of a nationally dominant ruling party. 
Against the backdrop of this imbalance, India in recent years witnessed an escalation in communal polarisation directed at Muslims, a trend that continued into the Covid-19 period. When infections began rising in the national capital and other cities, members of the Tablighi Jamaat sect were targeted by Hindu fundamentalists as 'super-spreaders' of the coronavirus (Salam 2020: 59-60). The Bombay High Court, in clearing Muslims of this pejorative label, was moved to remark that 'a political government tries to find the scapegoat when there is [a] pandemic or calamity' (Aurangabad Bench, Criminal Writ Petition No. 548 of 2020, 21 August 2020: para 27). Despite incidents like these, people in India generally responded supportively to government health measures, with community-driven food-relief initiatives for the needy coming into operation almost everywhere during the national lockdown.

\subsubsection{Taking the initiative}

In early January 2020, the government issued advisories to states to improve preparedness and health infrastructure in the event of a pandemic. On 18 January, thermal screening of passengers from China and Hong Kong was introduced at entry-points. A committee of five union ministers - those of health, aviation, shipping, home affairs, and foreign affairs - was formed to monitor the pandemic. On 11 March, the NEC, acting in terms of the DMA 2005, delegated powers to the union health secretary to boost preparedness and containment. Once a national disaster is in force, union ministries do not enjoy equal status but exercise their authority only with the consent and approval of the NDMA and NEC.

Point-of-entry surveillance was introduced by the end of January, and on 4 March, thermal screening was made mandatory for all international passengers. Travel bans, visa cancellation, and quarantining were effected from 13 March, and on 14 March, Covid-19 was (as noted) declared a national health emergency, which enabled states to withdraw monies from the State Disaster Response Fund (SDRF) (Parliament of India, Rajya Sabha 2020b: 6). States were instructed to ensure strict implementation of union advisories and guidelines. In terms of advisories issued by the Union Ministry of Health and Family Welfare, education facilities, cinemas, malls, and gyms were closed, and social and cultural gatherings were restricted. On $22 \mathrm{March}$, all international flights to India were suspended, as were mass transport services such as railways and buses. Domestic flights were suspended on 24 March.

On that same day, Prime Minister Modi, in a televised address at 20:00, announced a 21-day national lockdown, effective from midnight. The public had barely four hours' notice to gather essential items, nor for that matter had states or political parties been given much or any forewarning of the announcement (Mukherji 2020: 93); indeed, it was only later that night that chief secretaries of states were briefed about the lockdown (PIB 2020). Once the lockdown had been announced, states and political parties extended their support to the 
central government. For instance, the INC president, Sonia Gandhi, welcomed the decision in a public letter to the Prime Minister on 26 March, although also raising concerns among the medical fraternity about their safety and among workers about financial aid (The Print 2020a).

On 29 March 2020, the Union Home Secretary, as chair of the NEC, set up 11 specially empowered groups of officials to plan and manage the implementation of various aspects of pandemic response such as medical-emergency planning, disease surveillance, critical-care infrastructure, the supply of food and essential goods, and economic and welfare measures. Furthermore, working under the direction of the NEC, the Union Ministry of Health and Family Welfare coordinated health-care preparedness across states, issuing SOPs (standard operating procedures) and guidelines in this regard. The union agency, the Indian Council of Medical Research (ICMR), appointed technical experts to attend to the clinical aspects of health management, which included identifying laboratories in the states to conduct testing, and approve modes of treatment, drug prescriptions, and medical interventions.

Looking briefly at the initial state-level response, Kerala, led by the Communist Party, was the first to respond substantively to Covid-19. Even before the national lockdown, a stringent local lockdown was in effect, with schools having been closed and social gatherings banned; in fact, Kerala had issued coronavirus guidelines setting out case definitions and procedures for screening, quarantine, isolation, and treatment four days before India's first case of Covid-19 was reported on 30 January (NDMA 2020a). Rajasthan was also quick to respond to a possible emergency by taking measures in regard to quarantining and containment, with a state-wide curfew imposed on 18 March some days before the national lockdown. Likewise, Punjab adopted similar measures between January and early March. Prior to the lockdown, every state had a protocol of its own for contact tracing, isolation, and treatment.

Once Covid-19 had been declared a national pandemic on $14 \mathrm{March}$, states no longer had autonomy in their response measures and were obligated to follow national directives - if they wished to depart from them, they had to obtain permission in advance from the central government. Moreover, what was missing from the outset was the dimension of inter-state coordination - hardly any formal or informal inter-governmental mechanism was utilised.

\subsubsection{Federal government action}

In India, central government action in response to Covid-19 had four aspects to it. A first set of interventions were non-pharmaceutical and non-clinical and involved containing viral spread through closures, including lockdown and other modes of suspension and regulation of activity. A key outcome was that nationwide lockdown gave the central government time to ramp up health infrastructure. In the second place, there were pharmaceutical-clinical interventions carried out in terms of the regulatory guidelines of the ICMR and 
other central-level medical agencies. This involved centrally monitored hospital management and treatment of Covid-19 cases on a uniform national basis - to which one should hasten to add that it intruded significantly on state autonomy and jurisdictional authority over public health, given that states could not initiate medical measures contrary to central guidelines.

A third kind of action entailed providing information to the public about dietary and other means for building immunity, including through the use of Ayurvedic (alternative) medicine, while a fourth involved welfarist interventions geared towards the socio-economically vulnerable groups. This included supplying food relief over six months to two-thirds of the population (in the form of free rations consisting of $5 \mathrm{~kg}$ of rice and wheat and $1 \mathrm{~kg}$ of pulse foodstuffs such as beans and lentils) and paying INR 500 per month for an initial three months to about 200 million women holding accounts under the Pradhan Mantri Jan Dhan Yojana (PMJDY) financial inclusion programme; in addition, free gas cylinders were provided for three months to some 83 million families living below the poverty line (NDMA 2020b: 33).

The lockdown was effected through a series of orders issued by the Ministry of Home Affairs. The first 21-day national lockdown started on 25 March (Order No. 40-3/2020-DM-I/(A)). Except for the partial relaxation of the opening of states' administrative offices, and agricultural operations, the second lockdown order (MHA Order No. 40-3/2020-DM-I/(A), 15 April 2020) kept the stringency of the first and did not return states' powers. The third lockdown order (MHA Order No. 40-3/2020-DM-I/(A), 1 May 2020) brought some easing of trade restrictions allowing standalone shops in urban residential localities, and all shops in rural areas to operate. During the fourth lockdown (MHA Order No. 40-3/2020-DM-I/(A), 17 May 2020), states were allowed to start market operations with staggered opening times and Covid-19 preventive measures. States by mutual agreement were allowed to start interstate movement of vehicles. For better focused pandemic measures at the local level, the centre conceded the request of states to delineate red, green, and buffer zones in accordance with parameters laid down by the Union Ministry of Health and Family Welfare.

With the economic slump in sight, India started to unlock on a monthly basis from 1 June when hospitality services, markets, shopping malls, and limited religious worship in temples were allowed. During August the night curfew was removed and inter- and intra-state travel and transportation were permitted. In September, socio-religious, political, and academic gatherings could be held, while states were allowed to open schools and colleges and other educational institutions from 15 October.

Overall, pandemic governance under the institution of the NDMA consisted principally in executive governance little impeded by accountability to Parliament. As one contributor to the magazine Frontline observed, the pandemic seemed to have given the central government the opportunity to engage in 'muting parliament' (Ramakrishnan 2020: 21-23). 
Despite resistance from opposition parties, major instruments of parliamentary accountability were suspended during the legislature's 2020 monsoon session, namely, private members' bills, question hour (except for questions requiring written answers), and 'zero hour' (a procedural innovation allowing members to raise issues on matters of national concern without prior notice). Notably, too, the government did not accede to a demand for a debate on Covid-19, as this would have put it in the embarrassing position of explaining its handling of the pandemic and the effect it had on the economy.

The well-known parliamentarian Shashi Tharoor said the Modi government was attempting to reduce Parliament to 'a notice-board' and was '[using] its crushing majority as a rubber stamp for whatever it wants to pass' (cited in Ramakrishnan 2020: 21-22). This was especially true of labour laws passed during the monsoon session, and three controversial farm bills that were introduced and passed on the same day, thereby short-circuiting amendment procedures and truncating opportunity for debate in spite of stiff resistance from farmers, nonBJP-ruled states, and several regional political parties.

Together, the three bills - the Farmers' Produce Trade and Commerce (Promotion and Facilitation) Bill, the Farmers (Empowerment and Protection) Agreement on Price Assurance and Farm Services Bill, and the Essential Commodities (Amendment) Bill - leave India's farmers without security of pricing and the minimum guarantee of assured income and assistance they enjoyed hitherto. The effect of the three new legislative enactments is to privatise farming and bring agriculture within the ambit of inter-state trade, with the centre having exclusive jurisdiction - a move in keeping with the Modi government's wider efforts to use the pandemic as an occasion to promote privatisation and policy centralisation under the much-vaunted doctrine of Aatma Nirbhar Bharat ('self-reliant India').

This extends beyond agriculture. Although education is a concurrent subject, a new education policy (Union Ministry of Human Resource Development 2020) adopted in 2020 shifts the constitutional scales in favour of the centre rather than seeking to secure a fine federal balance between states and centre. Apart from promoting privatisation, the policy introduces structural changes in education governance by creating a single regulator for higher education as well as regulating the school curriculum, a matter that otherwise falls within the competence of states. In a similar vein, the Banking Regulation (Amendment) Bill of 2020 removes cooperative banking from the regulatory control of states and assigns it to the Reserve Bank of India.

\subsubsection{State government action}

As noted, prior to the declaration of a national disaster, states introduced measures of their own, given that they could issue orders under their state disaster management acts or state legislation on epidemics and public health. However, once central directions were issued, states had to comply with them. 
Kerala, for instance, allowed short-distance city bus travel and the reopening of local barber shops and restaurants. The centre considered it a violation of national lockdown measures, and the union home secretary instructed Kerala to adhere to them 'without any dilution and to ensure strict compliance [with] lockdown measures' (D.O. 40-3/2020-DM-I(A), 19 April 2020). The state was left with no choice but to rescind its order.

Nevertheless, states were allowed to introduce stricter containment measures if necessary. In addition, in later phases of the lockdown (1 June-31 October), they were permitted a partial degree of autonomy, but again only in accordance with central guidelines and SOPs.

The leeway available for individuality and locally responsive agency and innovation in state-level responses to the pandemic was thus highly constrained, a situation compounded by wide variation in resource capacities from one state to the next and hence in what each would be capable of doing anyway even if given a free hand. States largely performed similar functions such as border screening and control and enforcement of quarantining and isolation, although some states were innovative, as illustrated below:

- Kerala, with a highly decentralised and well-equipped public health system, followed a community-based approach in successfully containing two waves of Covid-19. It developed a network of neighbourhood surveillance systems for contact tracing. Its response further included effective provision of medicines, community kitchens, food relief, and social assistance worth INR 1,000 to families not receiving welfare grants (Kerala Chief Minister 2020).

- Karnataka optimised information technology and conducted a health-risk survey of about 15 million households that enhanced its management of Covid-19. It was also the first state to invoke provisions of the Epidemic Diseases Act, in addition to which it capped the cost of testing and hospitalisation in private hospitals (NDMA 2020c).

- Andhra Pradesh introduced innovations in ward surveillance and in managing multiple lockdowns, which were accompanied by highly regulated reopening.

- Tamil Nadu, apart from rigorously implementing lockdown measures, provided social assistance of INR 1,000 to all ration-card holders and INR 1,500 per month to persons with disabilities. (Most states provided free rations and cash transfers to the needy in the initial few months of lockdown.)

- Apart from implementing a community-based surveillance system, Madhya Pradesh introduced 'fever clinics' serving as '[first] points of contact for suspected Covid patients' (NDMA 2020d).

- Rajasthan's success story lies in decentralised public health and rigorous containment measures, while Punjab and Delhi were the first few states to introduce plasma therapy for Covid-19 treatment.

State high courts - notably in Delhi and Maharashtra, among others intervened, either on their own initiative or on the basis of public appeals, in 
matters relating to migrant workers, disease testing, the disposal of dead bodies, the condition of facilities in quarantine centres, and capping fees charged by private laboratories. During the August and September 2020 phased re-opening, state legislative assemblies began to convene; however, there are no inspiring tales of legislatures securing executive accountability in Covid-19 management.

The commanding authority of the central government was further upheld in two rulings by the Supreme Court of India. In Alakh Alok Srivastava v. Union of India, it pronounced that 'state governments, public authorities and citizens of this country will faithfully comply with the directives, advisories, and orders issued by the union of India in letter and spirit in the interests of public safety' (Supreme Court 2020, WP(C) No. 469). Then, in Praneeth K and Ors v. University Grants Commission (UGC) and Ors, it quashed the decisions of the SDMAs of Maharashtra and West Bengal to promote students to the following semester or year without holding year-end or term-end exams.

Stating that this was contrary to the guidelines of the University Grant Commission of India (UGC), the Court ruled that an SDMA was not authorised to take such a decision while the NDMA is in force. It also upheld the federal authority of the central government to regulate the examination and promotion of students in colleges and universities; conversely, SDMAs and other state authorities have no such jurisdiction (Supreme Court 2020, WP (C) No. 724).

\subsubsection{Local government action}

Although the 73rd and 74th Amendments to the Constitution in 1992 put panchayati raj institutions and municipal bodies on a sound constitutional footing, the devolution of functions, funds, and functionaries to them was left to the discretion of states (Basu 2020: 304). Some states, such as Kerala, Karnataka, and Rajasthan, have devolved considerable powers and authority to local bodies, while others, such as Bihar and Uttar Pradesh, are yet to do so. From the perspective of pandemic control, then, local government has been implemented unevenly and, in constitutional terms, is asymmetrically positioned in relation to state government.

Moreover, in terms of the DMA 2005, local bodies have to work under the control and direction of SDMAs. Their role ranges from raising public awareness about health issues and disposing of dead bodies to distributing welfare goods, providing sanitation and conducting community surveillance. In Kerala, for instance, panchayats were engaged, inter alia, in quarantine-centre work, door-to-door surveys, and keeping lists of migrants (Dutta and Fischer 2020). In Karnataka, they played a proactive role in delivering goods under government schemes in rural areas. In urban areas, municipal bodies were mainly responsible for the surveillance of hotspots and containment zones, over and above providing sanitation services.

In India, local bodies do not have the fiscal authority to defer or waive service charges, defer housing-loan payments, or grant concessions in property taxes, all of which are done either by states or the centre. For example, soon after the 
imposition of the first national lockdown, the central government announced that housing-loan repayments would be deferred for three months, later extending this by yet another three months; this measure did not affect local authority income, however.

\subsubsection{Intergovernmental relations}

Intergovernmental relations (IGR) are conducted both formally and informally (see Singh and Saxena 2015). The Constitution establishes the Inter-State Council to promote cooperation and coordination between the centre and states and among states on crucial issues of IGR and on matters of national importance. Its composition - consisting of all chief ministers, heads of union territories, the Prime Minister and six cabinet ministers of the union government - makes it a truly federal forum. However, in the three decades since it was constituted in 1990, it has met only 11 times, with the last meeting to date having been held in July 2016; on the matter of the global pandemic, it had not met once.

As for the DMA 2005, it does not provide any structured mechanism for IGR to facilitate policy consensus and coordination of measures among different levels of government. Instead, as noted, it institutes an executive, unilateral model of pandemic governance in which orders and commands flow top-down and permit only one-way traffic.

Informal mechanisms of intergovernmental relations include chief ministers' conferences and governors' conferences. Although not required to do so under the DMA 2005, Prime Minister Modi convened eight virtual meetings with state chief ministers and addressed the heads of local bodies once, and at the bureaucratic level, union home and health secretaries held several briefings and preparedness meetings with their state counterparts.

An overall assessment is that IGR has been at a low ebb in recent years and notably so in the Covid-19 period, with Prime Minister Modi showing scant regard for federal IGR institutions. At state level, instances of inter-state cooperation in pandemic management have been few and far between and, where they arose, limited to sharing cadres of health professionals, as happened between Kerala and Maharashtra.

In the grand scheme of pandemic governance, cooperative or competitive inter-state relations have little substantive role to play. For example, states have acted on their own rather than in concert in capping the prices of Covid-19 testing kits and treatment; at the same time, given that the centre monitors the prices of essentials, the resultant ceiling has prevented price wars or resource competition among the states.

\subsubsection{Intergovernmental fiscal relations}

The states raise about 52.5 per cent of their revenue, of which state GST constitutes about half of that (Reserve Bank of India 2019: 28-36), with central 
transfers constituting the remaining 47.5 per cent, following the recommendations of the Finance Commission of India. The decline in tax collection by the centre during the pandemic also caused a drop in the states' share of central taxes (Union Ministry of Finance 2020a).

The pandemic had a colossal impact on goods and service taxes (GST), which usually make up about 42 per cent of states' own tax revenue. Overall state GST collection in April-May 2020, India's two months of complete lockdown, declined by more than 44 per cent year-on-year, and in April-August, by more than 30 per cent; states' revenue deficit was estimated to be over INR 3,000,000 million (The Indian Express 2020a). Except Nagaland, which recorded a growth of 12 per cent, almost all states recorded a decline in the collection of state GST during April-August 2020 (Union Ministry of Finance 2020b).

Any shortfall in GST has an adverse impact on capital expenditure by states. Given that states ceded tax sovereignty in favour of a one-nation-one-tax model, a key issue is whether or to what extent the central government is under an obligation to compensate them for their GST shortfalls. It presented options for borrowing money from the Reserve Bank of India or from the open market, but non-BJP ruled states, such as Kerala, West Bengal, Punjab, and Delhi, demanded compensation to avoid the debt trap (The Indian Express 2020b).

As far as disaster funding is concerned, Bhaskar and Kelkar point out that, unlike the Government of India, 'state governments do not levy taxes/cesses to directly fund disaster relief' (Bhaskar and Kelkar 2019: 41). Annual expenditure in this regard is generally managed in four ways: by spending funds earmarked for relief expenditure such as 'gratuitous relief', food supplies, and the like; by tapping into funds allocated for capital works; by taking out loans for restoration work, such as 'repair of damaged houses and loans for purchase of agricultural inputs'; and by using money released from the SDRF (ibid). With a few exceptions, health infrastructure in India's states is poor; faced with the critical need to improve it yet also lacking adequate fiscal resources to meet expenditure on hospital facilities, quarantine centres, testing kits and similar necessities, states had to rely on the SDRF, other central assistance towards Covid-19 preparedness, and borrowing from the market.

Within the existing fiscal arrangements, disaster financing is shared between the centre and states in the ratio of 75:25 for general-category states and in the ratio of 90:10 for north-eastern and Himalayan states such as Uttarakhand and Himachal Pradesh. The Fifteenth Finance Commission, by way of grant-in-aid, allocates funds to the SDRF: for 2020-2021, the allocation was INR 289,830 million. SDRF funds are shared among states on the basis of criteria such as the state's size, population, disaster risk profile, and expenditure responsibility in regard to disaster management (Fifteenth Finance Commission 2019: 55-60). Unless permitted by the central government, states on their own may not withdraw from the SDRF (Union Ministry of Home Affairs 2020a).

As at 20 September 2020, releases from the SDRF totalled INR 115,659.25 million. The central government also released INR 16,246.3 million from 
the National Disaster Response Fund (NDRF) to give Manipur, Meghalaya, Odisha, Rajasthan, Tripura, and West Bengal additional support in their fight against Covid-19 (Union Ministry of Home Affairs 2020b). Assistance under the SDRF and NDRF was geared mainly towards meeting expenditure on quarantine measures and the procurement of essential equipment.

Moreover, states were provided with once-off central assistance of INR 42,567.9 million from the India Covid-19 Emergency Response and Health System Preparedness Package to set up dedicated hospitals and procure diagnostic and protection kits as well as other essentials for managing Covid-19. With a corpus fund of INR 150,000 million, the Package was created in April 2020 for strengthening national and state health systems and promoting pandemic research. Allocations to states were generally made on a combination of criteria such as case numbers and health infrastructure indexes (Union Ministry of Health and Family Welfare 2020a). To meet growing expenditure on health, states were also granted an additional borrowing limit of up to 2 per cent of gross state domestic product (GSDP) and permitted borrowing of 0.50 per cent of their respective GSDP from the market in the 2020-2021 financial year (Union Ministry of Finance 2020a).

In spite of these various measures by the central government, states have faced a severe cash-flow crisis. During April-June 2020, their fiscal deficit swelled to 36.5 per cent (The Print 2020b), adversely affecting expenditure on salaries and pensions as well as infrastructure, while their market borrowing in 2020-2021 soared to INR 3 trillion rupees - a figure estimated to be 52 per cent higher than borrowing in the previous year.

\subsection{Findings and policy options}

As this analysis shows, federalism in India was for all practical intents and purposes suspended during the Covid-19 pandemic in favour of highly centralised and personalised executive governance. The Indian polity accordingly tilted strongly towards unitary government: the power structure came to resemble a pyramid, with the Prime Minister placed at its apex and wielding extraordinary authority in commanding his subordinates at the state and local levels.

One explanation for this may be that the Constitution does not lay down a federal framework of pandemic governance. It is, indeed, a constitutional paradox that public health is a state matter, yet states are not allowed to govern it during a declared national disaster. The DMA 2005 entails a deeply unitary system of governance with little conformity to federal principles - as was evident in the practice it enabled, shaped, and sanctioned.

States were not part of central decision-making on the pandemic: a federal political culture of negotiated cooperation was missing, and neither states nor opposition parties were taken on board in any decision of the centre. Powers were concentrated in the centre; the normal functioning of centre-state relations was suspended. The centre exploited the pandemic to encroach upon important 
state-level fields such as agriculture, school and tertiary education, local economic, industrial and market operations, local transport, and intra-state movement of people and goods. The pandemic, in sum, did not retard or interrupt the general trend towards centralisation: it accelerated it.

Despite all the centre's measures, the pandemic continued to spread and intensify in its multiplying impacts. The lockdown failed to achieve its stated objective of breaking the chain of viral transmission; instead, the sudden declaration of a national lockdown caused the virus to spread from urban to rural areas due to massive labour migration. In the midst of all this, the federal government continued to control reporting on Covid-19 data, with the media and other independent agencies prevented from reporting any alternative information. The public had little option but to trust, or accept, central data on the pandemic.

By way of policy suggestions, there is, first, a need to review the DMA 2005, which was originally intended to respond to disasters on an emergency basis: it allows for short-duration centralisation and executive governance, but was never architected with a long-duration national pandemic emergency in mind. Thus, to cater for biological emergencies of an extended duration, it is necessary either to create a separate law or institution conforming to the principles of federalism and parliamentary accountability, or to amend the DMA 2005.

Secondly, the pandemic exposed the cracks in the system in India's primary and secondary levels of health care: even district hospitals, never mind grassroots facilities, lacked facilities adequate to the task of responding to a biological emergency. Given that the problem is due mainly to poor investment in health care, it needs to be re-emphasised, as has been done time and again, that the country should invest 2.5 per cent of its GDP in the health sector. The current budgetary allocation is insufficient to respond to biological emergencies such as Covid-19, while states are unable to meet rising health expenditure from their own pockets. There is hence a manifest need to revisit centre-state financial allocations.

\section{References}

Basu, Durga Das. 2019. 'Commentary on the Constitution of India' Articles 311 to 368, 9th ed.Vol. 14. Gurgaon: LexisNexis.

Basu, Durga Das. 2020. Introduction to the Constitution of India, 24th ed. Gurgaon: LexisNexis. Bhaskar, V. and Vijay Kelkar. 2019. 'Financing Disaster Management: Options for the GST Council and the Fifteenth Finance Commission', Economic \& Political Weekly, 54(25): 39-47.

Diamond, L. 2020. 'Democracy versus the Pandemic', Foreign Affairs, June 13, https://www. foreignaffairs.com/articles/world/2020-06-13/democracy-versus-pandemic (accessed on 13 February 2020).

Dutta, Anwesha and Harry W. Fischer. 2020. 'The Local Governance of Covid-19: Disease Prevention and Social Security in Rural India', World Development, 138: 105234.

Fifteenth Finance Commission. 2019. Report for the year 2020-21. New Delhi: PRS. 
Gandhi, Supriya. 2020. 'When Toppling Monuments Serves Authoritarian Ends: India's Hindu Nationalists Erects an Imagined Past on Modern Ruins,' Foreign Affairs 13 July. https://www.foreignaffairs.com/articles/india/2020-07-13/when-topplingmonuments-serves-authoritarian-ends (accessed on 28 July 2020).

Jaffrelot, Christophe and Utsav Shah. 2020. 'The Health Care Gap', The Indian Express, 9 June.

Jain, M. P. 2019. Indian Constitutional Law, 7th ed.Vol. 1. Gurgaon: LexisNexis.

Kerala Chief Minister. 2020. 'Kerala’s Fight against Covid-19', Official Website of Chief Minister of Kerala Pinarayi Vijayan, https://www.keralacm.gov.in/kerala-fight-against-covid-19/ (accessed on 24 September 2020).

Maps of India. 2020. 'Ruling Parties in Different States of India.' https://www.mapsofindia. com/maps/india/states-political-parties.html (accessed on 3 December 2020).

Office of the Registrar General and Census Commissioner of India, 2011. '2011 Census Data', https://censusindia.gov.in/2011-common/censusdata2011.html (accessed on 13 February 2020).

Mukherji, Rahul. 2020. 'Covid vs. Democracy: India’s Illiberal Remedy', Journal of Democracy, 31(4): 91-105.

National Disaster Management Authority (NDMA). 2020a. 'Response to Covid-19: Kerala', https://ndma.gov.in/sites/default/files/PDF/covid/response-to-covid19-by-kerala.pdf (accessed on 20 October 2020).

National Disaster Management Authority (NDMA). 2020b. COVID-19 Impacts and Responses: The Indian Experience, January-May 2020. India: NDMA, https://ndma. gov.in/sites/default/files/PDF/covid/COVID-19-Indian-Experience.pdf (accessed on 20 October 2020).

National Disaster Management Authority (NDMA). 2020c. 'Response to COVID-19: Karnataka', https://www.ndma.gov.in/sites/default/files/PDF/covid/response-to-covid19by-karnataka.pdf (accessed on 20 October 2020).

National Disaster Management Authority (NDMA). 2020d 'Response to COVID-19: Madhya Pradesh', https://ndma.gov.in/sites/default/files/PDF/covid/MP_English.pdf (accessed on 20 October 2020).

Nomani, Zafar Mahfooz and Rehana Parveen. 2020. 'Contextualising Epidemic Diseases (Amendment) Ordinance, 2020 in Epidemic-Pandemic Syndrome of Covid-19 in India', Systematic Reviews in Pharmacy, 11(8): 156-160.

Parliament of India, Rajya Sabha. 2020a. '229 Report on the "Management of Covid-19 Pandemic and Related Issues" of the Departmentally Related Standing Committee on Ministry of Home Affairs'. Report presented on 21 December.

Parliament of India, Rajya Sabha. 2020b. '123 Report on "the Outbreak of Pandemic Covid-19 and its Management" of the Departmentally Related Standing Committee on Ministry of Health and Family Welfare'. Report presented on 17 November.

Patnaik, Prabhat. 'Shadow of Fascism.' 2020. Frontline, April 12, https://frontline.thehindu. com/cover-story/article26641337.ece (accessed on 13 February 2020).

Picketty, Thomas. 2020. Capital and Ideology. Cambridge MA:The Belknap Press of Harvard University Press.

Press Information Bureau (PIB). 2020. 'States Briefed on Lockdown Measures and Guidelines', Release ID: 1608012, 24 March, https://pib.gov.in/Pressreleaseshare.aspx? PRID=1608012 (accessed on 24 March 2020).

PRS Legislative Research. 2020a. 'Demand for Grants 2020-21 Analysis: Health and Family Welfare', https://www.prsindia.org/parliamenttrack/budgets/demand-grants-2020-21analysis-health-and-family-welfare (accessed on 18 May 2020). 
PRS Legislative Research. 2020b. 'The Epidemic Diseases (Amendment) Bill, 2020', http:// www.prsindia.org/billtrack/epidemic-diseases-amendment-ordinance-2020 (accessed on 3 December 2020).

Ramakrishnan,Venkitesh. 2020. 'Muting Parliament', Frontline, 37(19), 21-23.

Reserve Bank of India (RBI). 2019. State Finances: A Study of Budgets of 2019-20. Mumbai: RBI.

Reserve Bank of India (RBI). 2020. Press Release: 2020-2021/623, 11 November, https:// www.rbi.org.in/Scripts/BS_PressReleaseDisplay.aspx?prid=50650 (accessed on 13 November 2020).

Salam, Ziya Us. 2020. 'Tablighi Jamaat: Vindicated, Finally', Frontline, 37(19). September 25, https://frontline.thehindu.com/the-nation/vindicated-finally/article32516103.ece (accessed on 13 February 2020).

Singh, Ajay Kumar. 2009. Union Model of Indian Federalism. New Delhi: Manak Publications.

Singh,Ajay Kumar. 2015. 'Constitutional Semantics and Autonomy within Indian Federalism', in Fransceco Palermo and Elisabeth Alber (eds), Federalism and Decision Making: Changes in Structures, Procedures and Policies, pp. 120-47, Leiden: Brill Nijhoff.

Singh, Ajay Kumar. 2019. 'An Emerging National Federalism.' Seminar, 717: 68-71.

Singh, M. P. and R. Saxena. 2015. 'Intergovernmental Relations in India: From Centralisation to Decentralisation', in Johanne Poirier, Cheryl Saunders, and John Kincaid (eds), Intergovernmental Relations in Federal Systems: Comparative Structures and Dynamics, pp. 239-271, Don Mills: Oxford University Press.

Tharoor, Shashi. 2020. The Battle of Belonging: On Nationalism, Patriotism and what it means to be Indian. New Delhi: Aleph Book Company.

The Indian Express. 2020a. Issues in GST Compensation, p. 13, August 29.

The Indian Express. 2020b. GST Revenue Deficit: 20 States Get Nod to Borrow Rupees 68, 825 Cr, p. 15, October 14.

The Print. 2020a. 'In a Letter to PM Modi, Sonia Gandhi Says 21-Day Coronavirus Lockdown a "Welcome Step", 26 March, https://theprint.in/india/in-letter-to-pmmodi-sonia-gandhi-says-21-day-coronavirus-lockdown-a-welcome-step/388697/ (accessed on 14 September 2020).

The Print. 2020b. '52\% Higher Borrowing: Big Drop in Revenue - Why States Are Despairing about Their Finances', http://theprint.in/india/governance/52-higherborrowing-big-drop-in-revenue-why-states-are-desparing-about-their-finances/ 501948/ (accessed on 19 October 2020).

Union Ministry of Finance. 2020a. 'Monthly Review of Accounts of Union Government of India Up to the Month of September, 2020 for the Financial Year 2020-21', https://pib. gov.in/PressReleasePage.aspx?PRID=1668448 (accessed on 29 October 2021).

Union Ministry of Finance. 2020b. Reply to Rajya Sabha Unstarred Question No 206, 15 September 2020.

Union Ministry of Health and Family Welfare. 2020a. PIB release ID 1669006. 31 October, http://pib.gov.in (accessed on 31 October 2020).'

Union Ministry of Home Affairs. 2020a. Reply to Lok Sabha Unstarred Question No. 1541. 20 September 2020.

Union Ministry of Home Affairs. 2020b. 'Press Release: Stimulus Package for COVID-19', 15 September, https://pib.gov.in/PressReleasePage.aspx?PRID=1654599 (accessed on 15 September 2020).

Union Ministry of Human Resource Development. 2020. National Education Policy 2020. https://www.education.gov.in/sites/upload_files/mhrd/files/NEP_Final_English_0.pdf (accessed on 20 October 2020).

Union Ministry of Information and Broadcasting. 2020. India 2020. New Delhi: Principal Director General, Publication Division. 
Union Ministry of Law and Justice. 2019. The Citizenship (Amendment) Act, 2019. http:// egazette.nic.in/WriteReadData/2019/214646.pdf (accessed on 15 October 2020).

United Nations, Department of Economic and Social Affairs, Population Division. 2019. World Population Prospects 2019: Highlights. New York: United Nations.

Vyas, Mahesh. 2020.'21 Million Salaried Jobs Lost', Centre for Monitoring Indian Economy

(CMIE), 5 September, https://www.cmie.com/kommon/bin/sr.php?kall=warticle\&dt= 2020-09-07\%2017:57:52\&msec=996 (accessed on 20 Sept 2020).

World Bank. 2020. GDP Growth (Annual \%) - India, https://data.worldbank.org/indicator/ NY.GDP.MKTP.KD.ZG?locations=IN (accessed on 20 October 2020).

Yadav, Yogendra. 2020. Making Sense of Indian Democracy. Ranikher: Permanent Black. 